„Kwartalnik Filmowy” nr 113 (2021)

ISSN: 0452-9502 (Print) ISSN: 2719-2725 (Online)

https://doi.org/10.36744/kf.674

(c) Creative Commons BY-NC-ND 4.0

\title{
Michał Dondzik
}

Uniwersytet Łódzki

https://orcid.org/oooo-0002-6661-7420

\section{Obraz, technologia i film polski. Dziworski, Rybczyński i Królikiewicz}

\author{
Slowa kluczowe: \\ Bogdan Dziworski; \\ Zbigniew \\ Rybczyński; \\ Grzegorz \\ Królikiewicz; \\ film polski; \\ sztuka operatorska; \\ technika filmowa
}

\begin{abstract}
Abstrakt
Artykuł jest próbą spojrzenia na filmy Na wylot (1973), Wieczne pretensje (1975) i Tańczacy jastrzab (1978) Grzegorza Królikiewicza przez pryzmat techniki filmowej. W artykule autor przywołuje wspomnienia operatorów tychże filmów: Bogdana Dziworskiego i Zbigniewa Rybczyńskiego, uzupełniając je relacjami innych osób zaangażowanych w twórczy i technologiczny proces powstawania dzieł. Zebrane po latach wspomnienia filmowców zostają skonfrontowane z relacjami prasowymi z planów produkcji, a także dokumentami znalezionymi podczas szeroko zakrojonej kwerendy archiwalnej. Celem artykułu jest odsłonięcie relacji między artystycznymi aspiracjami operatorów i reżysera a technicznymi możliwościami kinematografii Polski Ludowej.
\end{abstract}


Mnie scenariusz mniej interesowat, raczej chodzito o emocje, o pomysty na sceny. Zajmowałem sie forma․

Bogdan Dziworski

Jak robitem swoje obrazy, to bardzo mnie interesowata metoda, w jaki sposób ludzie malowali w przeszłości. Sam namalowałem obraz gotycki, renesansowy, barokowy. Wszystkie te laserunki, warstwy, problemy techniczne mnie ciekawity. Zdałem sobie sprawe z podstawowej sprawy, że film też jest technika ${ }^{2}$.

Zbigniew Rybczyński

Bergson zauważyt, że umyst ludzi zbliżony jest do kinematografu. Zasada ta dotyczyła w swoim czasie wyłacznie umysłów nieprzeniknionych. Dziś, dzięki rozwojowi środków przekazu, stała się ona reguła niemal powszechna. Dlatego właśnie podstawowe do niedawna dla reżysera pytanie "co" winno zostać wyparte pytaniem , jak"3.

Grzegorz Królikiewicz

Refleksja o technologii filmowej odgrywa marginalną rolę $\mathrm{w}$ historii kina Polski Ludowej. Na brak zainteresowania badaniami nad sprzętem, taśmą filmowa innowacjami technicznymi i ich wpływem na estetykę złożyło się wiele powodów. Podstawową przyczyną jest dominująca rola analizy samego dzieła filmowego z pominięciem kontekstów realizacyjnych. Trudności w badaniach nad technologią filmową wynikają również z faktu, że twórcy niechętnie dzielili się tajnikami metod pracy, traktowali kwestie techniczne raczej jako element warsztatu filmowego niż sztuki. Uboga i rozproszona jest także dokumentacja - zapiski w teczkach produkcji często ograniczają się do wzmianki o sprzęcie. Ponadto jak wiadomo twórców w PRL dotykały ograniczenia sprzętowe, limity taśmy filmowej i niedobór podstawowych środków. Jakie zatem rozwiązania technologiczne były wtedy stosowane?

Poniższe rozważania są jedynie przyczynkiem do refleksji nad trzema filmami: Na wylot (1973), Wieczne pretensje (1975) oraz Tańczacy jastrzą (1978). Praca ta nie stanowi kompletnej analizy, która dotyczyłaby wszystkich aspektów technologicznych wymienionych produkcji. Jej celem jest ukazanie na wybranych przykładach związków między koncepcjami estetycznymi (operatorów - Bogdana Dziworskiego i Zbigniewa Rybczyńskiego oraz reżysera - Grzegorza Królikiewicza) z technologicznymi możliwościami realizacyjnymi w Polsce Ludowej.

\section{Na wylot - Bogdan Dziworski i innowacje techniczne}

$\mathrm{Na}$ wylot Grzegorza Królikiewicza to jeden z najciekawszych debiutów w dziejach polskiego kina. Film opowiada historię Jana Malisza (Franciszek Trzeciak) i jego żony Anny (Anna Borowa). Odrzuceni przez społeczeństwo bohaterowie, z zemsty i chęci odzyskania godności, dokonują brutalnego morderstwa. Podczas rozprawy sądowej widzowie są świadkami „dowodów” miłości, w imię której każde z małżonków próbuje ocalić partnera i wziąć winę na siebie. 
Z twórczością Bogdana Dziworskiego - autora zdjęć do Na wylot - Grzegorz Królikiewicz zetknął się w trakcie studiów prawniczych. Reżyser wspominał: Zobaczyłem pod siódemkami [ulica Piotrkowska 77 w Łodzi] wernisaż: łódzkie podwórka i anemiczne dzieci przeżywajace pierwiosnki miłości, zapatrzone w siebie jak kochankowie. Bodzio to fotografowat. Nie znałem go w ogóle, zobaczyłem wernisaż "vis à vis" mojego mieszkania na Piotrkowskiej i wracałem tu przez kilka dni. To było coś obezwładniajacego ${ }^{4}$. Chwilę, w której otrzymał propozycję realizacji zdjęć do Na wylot, Dziworski zapamiętał następująco: Wyjechałem do Bułgarii, tam miałem do wykonania zadania fotograficzne i filmowe ${ }^{5}$. Królikiewicz przysłat mi telegram: "Wracaj do Polski, jest dużo do roboty”. Wrócitem do kraju, zrobiłem z Ryszardem Czekała film "Wypadek” w krakowskim Studiu Miniatur Filmowych, Królikiewicz ten film zobaczył i zaproponowat mi prace przy "Na wylot"6.

Treść filmu była dla autora zdjęć mniej ważna niż sposób jej ukazania; mówił: Mnie scenariusz mniej interesowat, chodziło o emocje, pomysty na sceny. Zajmowatem sie forma ${ }^{7}$. Z kolei Grzegorz Królikiewicz przedstawiał formalne aspiracje tak: Bergson zauważyt, że umyst ludzi zbliżony jest do kinematografu. Zasada ta dotyczyła w swoim czasie wyłacznie umysłów nieprzeniknionych. Dziś, dzięki rozwojowi środków przekazu, stała się ona reguła niemal powszechna. Dlatego wtaśnie podstawowe do niedawna dla reżysera pytanie "co" winno zostać wyparte pytaniem "jak". Problem formy staje sie sprawa palaca, ponieważ - wracając do aforyzmu Bergsona - już sama tylko forma filmowa można wyrazić strukturę ludzkiego umystu i stan naszej emocji ${ }^{8}$. Idąc tropem tej myśli, warto się przyjrzeć, jak w Na wylot wykreowana została warstwa wizualna.

Założeniem Grzegorza Królikiewicza była realizacja filmu w dwóch porządkach wizualnych. Za sceny filmowane kamerą z ręki odpowiedzialny był Bogdan Dziworski, dysponujący doskonałym zmysłem obserwacji, wynikającym z wieloletniej pracy przy fotografii ulicznej. Jednak część zdjęć w Na wylot stanowią ujęcia statyczne, których realizacja przypadła w udziale Zdzisławowi Kaczmarkowi. Ja byłem szwenkierem i jeżeli coś kręciliśmy na dwie kamery, to byłem też operatorem. Królikiewicz dał mi dodatkowa funkcję, miałem dbać o ciagłość stylu. Kiedy mówiłem, że nie można czegoś $w$ danej scenie zrobić w taki sposób, to tego nie robiono ${ }^{9}$ - wspominał filmowiec. Niektóre sceny (w melinie i w sądzie) kręcono dwiema kamerami. Zdjęcia z ręki powstały przy użyciu kamery Arriflex 2C (mieszczącej kasety na $150 \mathrm{~m}$ taśmy ${ }^{10}$ ), z kolei w scenach ze zdjęciami „setkami” wykorzystywano kamerę Arri $300^{11}$. Reżyser wyjaśniał: Jedna kamera była zaplanowana absolutnie, druga to strefa improwizacji $i^{12}$.

Realizacja filmu w oparciu o dwa typy ujęć oddających kontrast rytmiczny między statycznością i dynamizmem, określana przez Królikiewicza jako metoda syntetyzowania skrajności stylistycznych ${ }^{13}$, nie była jedynym założeniem formalnym reżysera. Część scen została nakręcona w poetyce amerykańskiego kina bezpośredniego - filmów dokumentalnych, będących próbą odrzucenia nagromadzonych konwencji tradycyjnego kina w nadziei ponownego odkrycia rzeczywistości, która umyka innym formom filmu i reportażu. (...) Filmowcy staraja się wyeliminować bariery między pokazywana rzeczywistościa a odbiorca. Sa to bariery techniczne (duża ekipa, studio, kamera na statywie, oświetlenie, kostiumy, makijaż), proceduralne (scenariusz, aktorstwo, ré̇yseria) i strukturalne (standardowe chwyty montażowe, tradycyjne formy melodramatu, suspens itp.). Kino bezpośrednie to praktyczna metoda oparta na wierze w niezmanipulowana rzeczywistość, na odrzucaniu wszelkiej ingerencji w życie, które się samo prezentuje $e^{14}$. 
Znanym przykładem kina bezpośredniego, do którego odwołał się Królikiewicz, jest film Primary (reż. Robert Drew, 1960) ${ }^{15}$. Polskiemu reżyserowi zapadła w pamięć scena spotkania biorącego udział w prawyborach Partii Demokratycznej Johna F. Kennedy'ego z Polonią w Milwaukee ${ }^{16}$. Królikiewicz zapamiętał jedno z ujęć: Moment obserwacji Jacqueline Kennedy, kiedy podaje rękę kolejnym obywatelom, potencjalnym zwolennikom męża, i następuje obserwacja, obsesyjna wręcz, skurczów jej mięśni twarzy i szyi ${ }^{17}$. W Na wylot można wskazać co najmniej kilka podobnych ujęć, m.in. zbliżenie grdyki Malisza pochłaniającego resztki jedzenia z kubła na odpadki, jego zaciśniętych ust czy wyeksponowanie zmarszczek na szyi ofiar morderstwa. To jest ta bezpośredniość w oglądaniu wszystkich relacji, gdzie przekracza się próg behawioralnej uzewnętrznionej obserwacji i docieka się czegoś więcej ${ }^{18}$ - tłumaczył twórca.

Najbliższa poetyce kina bezpośredniego jest scena otwierająca film, która rozgrywa się w melinie. Do udziału w niej zostali wybrani ludzie z tzw. marginesu społecznego. Wśród nich znaleźli się także przestępcy - Jerzy Zalewski vel „Jurek Zalewaja” (filmowy Jurek) oraz Aleksander Czajczyński znany jako „Olek Brudas"19. Naturszczykom (w tym również Annie Borowej) partnerowały osoby związane z filmem (Franciszek Trzeciak, Edward Radulski, muzyk Marcel Novek oraz aktorka teatralna Ewa Zdzieszyńska). Ci ludzie musieli się wprowadzić w alkoholowy nastrój, swobodę, zgubić to, że jest kamera - świadek ${ }^{20}$ - wspominał operator dźwięku Jerzy Wroński. Chodzito o to, żeby ich nie rozpraszać, kamere mieliśmy schowana w cieniu. Oni po niedługim czasie, w miarę doprowadzania procentów alkoholu, zapomnieli, że jest kamera. Głównie to była rejestracja pewnego żywiołu. Można powiedzieć, że scena na melinie jest bardziej dokumentem niż inscenizowana fabuła ${ }^{21}$ - dopowiadał Zdzisław Kaczmarek. Elementem jednoczącym osoby biorące udział w tej scenie, wywodzące się przecież z tak różnych porządków, było miejsce realizacji - autentyczna melina, w której w celu realizacji zdjęć zorganizowano całonocną libację. Spowodowało to zatarcie granic między filmową fikcją a dokumentalną rejestracją rzeczywistości. Scene zrobiliśmy w ciagu jednej nocy, kręciłem ja przy jednej żarówce. Elektrycy nie wierzyli, że to wyjdzie. Wszystko było autentyczne, oczywiście była wódka, były śledzie $e^{22}$ - wspominał Bogdan Dziworski. Użyto dwóch kamer - jedna, umieszczona na statywie, krążyła w położona ósemke, znak nieskończoności², druga wyłapywała pojedyncze obserwacje $e^{24}$. To wszystko było wykreowane ruchami okrężnymi kamery i kontrastowym świattem ${ }^{25}$ - mówił autor zdjęć. Mimo zastosowania rozwiązań charakterystycznych dla kina dokumentalnego mających przybliżyć widza do przedstawianej rzeczywistości celem twórcy nie była dokumentalna rejestracja pijatyki.

Kolejną inspiracją Królikiewicza był okres w historii kina, który reżyser określa jako obszar ekspresjonizmu niemieckiego aż po „Obywatela Kane'a”26. Stwierdzenie to może wydawać się zaskakujące - cóż bowiem ekspresjonizm filmowy, zapoczątkowany przez słynny Gabinet doktora Caligariego (reż. Robert Wiene, 1920), mógłby mieć wspólnego ze zrealizowanym w latach 70. w Polsce Ludowej Na wylot? W ekspresjonizmie istotną rolę odgrywały elementy takie, jak nierealistyczna scenografia, nienaturalna gra aktorów stapiających się z dekoracjami, statyczna kamera, cienie rzucane przez postacie ${ }^{27}$. Tym, co łączy Na wylot z filmami ekspresjonistycznymi, a także z kinem sprzed przełomu dźwiękowego w ogóle, jest milczenie bohaterów. U Królikiewicza zabieg ten ma przygotować widza na 
mówioną scenę finałową. Ekspresjonistyczny charakter filmu nie wynika z kopiowania rozwiązań stylistycznych znanych z kina weimarskiego, lecz z przetworzenia zasady tego nurtu. W Na wylot, tak jak w ekspresjonizmie, świat wewnętrzny postaci znajduje odzwierciedlenie w świecie zewnętrznym. Królikiewicz wyjaśniał to na przykładzie sceny, w której Malisz szuka pracy jako dzwonnik: To opowieść o sercu Malisza, które huczy, krzyczy - ludzie, weźcie mnie do siebie, dajcie mi pracę, ja nie wiem, co zrobie, tym bardziej że żona we mnie watpi, upokarza mnie. To jest krzyk serca - te dzwony. A to jest już ekspresjonizm. Co w duszy, to na powierzchni28.

Nawiązaniem w debiucie Królikiewicza do filmu niemego i nurtu ekspresjonistycznego jest także sposób użycia światła. We wczesnym okresie rozwoju kina filmy kręcono na taśmie ortochromatycznej, która utrwalała barwę zielona, niebieską i żółtą. Potem zastąpiła ją taśma panchromatyczna, której emulsja była czuła na wszystkie barwy. Na wylot powstał na czarno-białej taśmie ORWO NP-729 o czułości $24 \mathrm{DIN}^{30}$. Jest to taśma wysokoczuła - wyjaśniał Wiesław Stempel - gruboziarnista, dajaca wysoki kontrast. Ponieważ panuje obecnie moda na brud, na efekty pseudodokumentalne w fabule - tę taśmę operatorzy stosuja ${ }^{31}$. To byt najgorszy sort materiału enerdowskiego, czarno-białego, który się różnit w osiach i emulsjach. Normalne zachodnie taśmy były cukierkowe, a tutaj brutalność taśmy była nam na rękę $e^{32}$ - opowiadał Bogdan Dziworski. Na wylot jest jedynym polskim filmem fabularnym z 1973 r., który nakręcono na taśmie czarno-białej ${ }^{33}$.

Reżyser tak uzasadniał nowatorski zamysł warstwy wizualnej: Chodziło nam o to, by uzyskać, narzucić efekt światła niedzisiejszego, by poprzez światło natychmiast wpisać epokę. Wydawało nam się (czuję się w tych sprawach laikiem, głos decydujacy miat operator - Bogdan Dziworski), że wszystko traktować należy w sposób naturalistyczny $z$ wyjątkiem światta, które pochodzi jak gdyby z lat 30. (...) Postanowiliśmy wykorzystać cała wysoka czułość obecnej taśmy, a jednocześnie odebrać jej dzisiejszy fatsz walorowy i powrócić do przekładania np. barwy czerwonej na walor czarny ${ }^{34}$. Królikiewicz chciał, by forma dotykała również samego negatywu 35 . Realizacja filmu w 1972 r. na używanej na początku XX w. taśmie ortochromatycznej była niemożliwa, jej efekt Bogdan Dziworski uzyskał, stosując oświetlenie jarzeniowe, co było pomysłem prekursorskim, a zarazem ryzykownym. Nie ma filmowych reflektorów, sa tylko dwie lekkie, przenośne tablice z wmontowanymi rurkami neonowych jarzeniówek. Świeca fioletowym, trupim blaskiem, maja dać specyficzna fakture zdjęć, zbliżona do starych dokumentalnych fotografii ${ }^{36}$ - relacjonował z planu jeden z dziennikarzy. Świecenie jarzeniówkami to specyficzne światło, nie chodzi o kolor, film byt czarno-biały, ale zachowujac kierunkowość, jest niestychanie miękkie ${ }^{37}$ - komentował zaś Zdzisław Kaczmarek. Konstrukcja lampy była dość prosta. Jarzeniówki zamocowano na trójnożnej podstawie podobnej do tradycyjnego statywu. Aby ułatwić przestawianie światła, do każdej z nóżek przytwierdzono koło; można było także regulować wysokość głównego ramienia, na którym znajdowały się jarzeniówki. Światła ulokowano w dwóch rzędach w prostokątnej metalowej oprawie ${ }^{38}$. Sam wynalazek - opowiadał Bogdan Dziworski - polegat na tym, żeby za pomoca rur jarzeniowych oświetlić plan tak, by światło nie drgało. Jarzeniówki powoduja drgania. Żeby nie byty widoczne przerwy w drganiach, jedna jarzeniówka gasła, a zapalaliśmy drugą. Ja kręciłem na kamerze z sektorem. Kiedy światto miało ileś tam cykli, wpadało w cykl kamery i powstawało mruganie, aby to usunać, przeciwfazowo podłaczaliśmy źródła światła. Z tym oświetleniem były duże trudności, nikt nie chciat wierzyć, że się uda. Królikiewicz uwierzyt, ja uwierzyłem i poszło ${ }^{39}$. 
Scena w sądzie z oświetleniem jarzeniowym wymyślonym przez Bogdana Dziworskiego
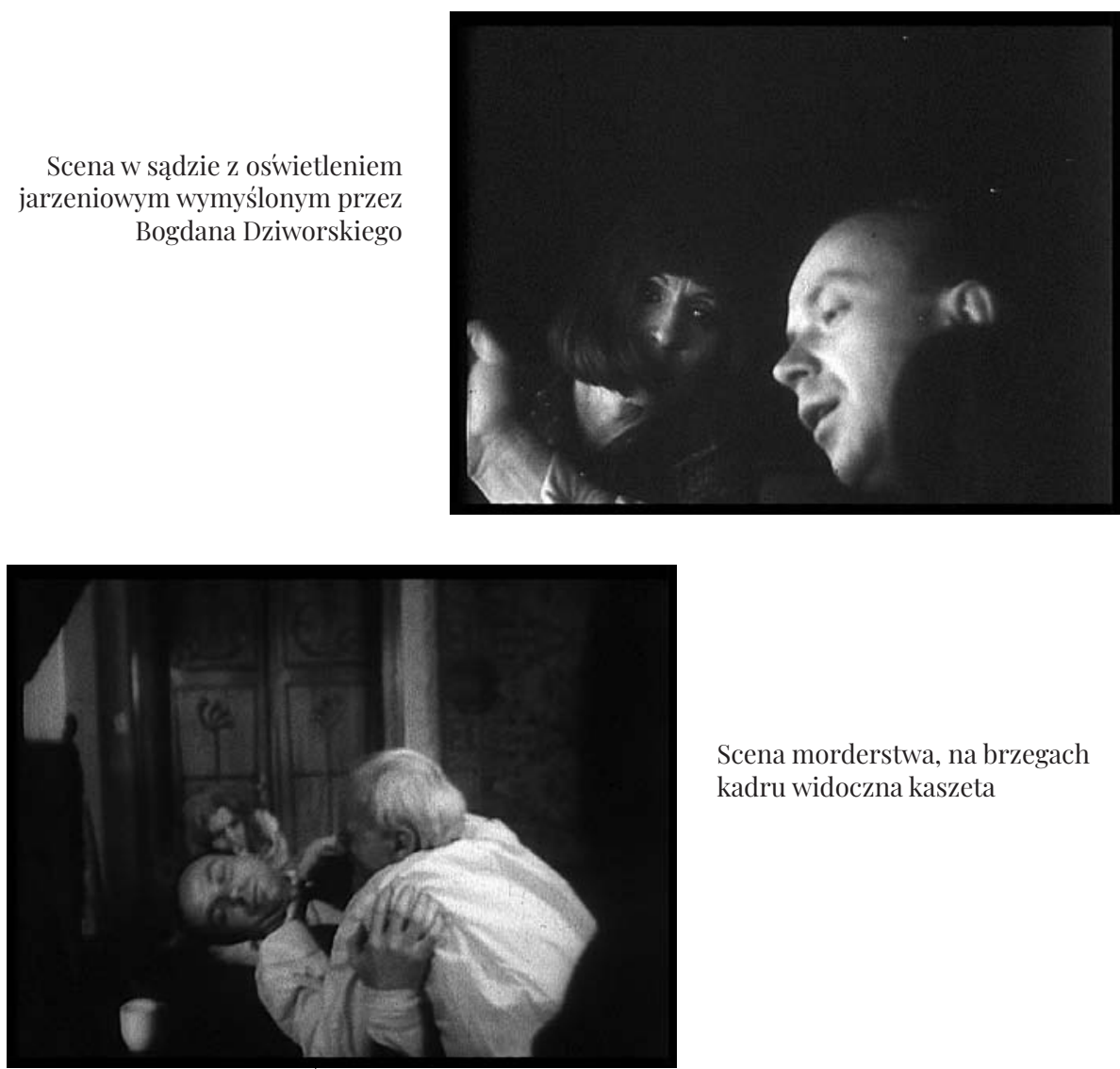

Scena morderstwa, na brzegach kadru widoczna kaszeta

Na wylot, reż. Grzegorz Królikiewicz (1973)

Wydaje się, że w ujęciach zarówno statycznych, jak i dynamicznych kamera pracuje na własnych zasadach, niejako niezależnie od ukazywanych zdarzeń. $\mathrm{Na}$ mawiałem - wyjaśniał reżyser - Bogdana i Zdzisława Kaczmarka, żeby starali się swingować, nie powtarzali tego, co życie niesie, lecz próbowali zawartość kadru rozkładać na określone rytmy. To swingowanie kamery zaczyna się już w scenie meliny, a kończy w scenie hotelu ${ }^{40}$; i dodawał: Ten swing kamery zaczyna się, kiedy Malisz zrywa ze swoja dotychczasowa kochanką. Ona się żali, wykrzykuje, ale w chwili najwyższego natężenia jej wulgarnej oracji kamera ja porzuca, jak gdyby nic sie w tej kobiecie nie działo, i obserwuje rzeczy zupetnie neutralne. Ta zasada została doprowadzona do skrajności w scenie w hotelu. Kamera, w powracajacym rytmie panoram, żyje własnym życiem, niezgodnym zupetnie z rytmem działań aktorów, którzy leża na tóżkach ${ }^{41}$.

Realizacja dynamicznych, długich ujęć kamerą prowadzoną z ręki jest współcześnie - dzięki rozwojowi techniki, m.in. steadikamowi - standardem. Ten epokowy wynalazek został użyty po raz pierwszy w 1976 r. w hollywoodzkim filmie By nie petzać na kolanach (Bound for Glory, reż. Hal Ashby) ${ }^{42}$. W Polsce Ludowej filmy realizowano inaczej. Wedle Bogdana Dziworskiego: Zwykle kamerę trzymało się na stelażach opartych o brzuch. W trakcie wdechu i wydechu następowały ruchy kamery, ale nie takie, jak trzeba ${ }^{43}$. 
W 1972 r. - kiedy powstawało Na wylot - realizacja sceny poszukiwania pracy przez Malisza zdawała się zadaniem karkołomnym. Nakręcenie tego ponadtrzyminutowego ujęcia nie byłoby możliwe bez wynalazku, który - na potrzeby publikacji - nazwę kolbą Niedbalskiego. Bogdan Dziworski wspominał: Będac drugim operatorem przy filmie Kazimierza Karabasza "Ptaki”, zobaczyłem ten przyrzad, chciałem go mieć. Stasiu Niedbalski nie był skłonny podzielić się patentem, a ponieważ uwielbiat soczki owocowe, postawitem mu cztery, a sam wdarłem się do jego pokoju w hotelu, odrysowatem przyrzad i tak stałem się jego posiadaczem. (...) Autorem wynalazku byt Stanisław Niedbalski, pomysł ukradł Bogdan Dziworski ${ }^{4}$. Kolba Niedbalskiego to konstrukcja z aluminium i drewna mocowana do silnika kamery Arriflex. Wynalazek dawał wsparcie w jednym punkcie na ramieniu. Jego atutem była mobilność, możliwość płynnego przejścia z ujęcia prowadzonego z ręki do ujęcia statycznego dzięki wczepieniu kolby w statyw ${ }^{45}$. Dla Dziworskiego istotne było zachowanie niedoskonałości ruchu kamery prowadzonej z ręki, a nie jego wyrównanie typowe dla steadikamu: Chodziło o to, aby rytm chodzenia był zaznaczony, człowiek nie chodzi płynnie, jest to sprawa pewnych ruchów. Praca ręka-ramię jest lepsza, człowiek ten rytm wyczuwa, wie, kiedy przystopować, wytrzymać. Kamera z ręki jest ciekawa, autorska ${ }^{46}$.

Efektem pracy prowadzonej z ręki, swingującej kamery jest w $\mathrm{Na}$ wylot właśnie scena poszukiwania przez Malisza pracy w wydawnictwie prasowym. W scenopisie rozgrywała się ona w kantorze, w którym, poza parą bohaterów, pojawiał się syn fabrykanta oznajmiający, że ten ich nie zatrudni. Brakuje tu informacji o wizualnej koncepcji fragmentu ${ }^{47}$. Zmiana miejsca była efektem pomysłu scenografa Zbigniewa Warpechowskiego ${ }^{48}$, który zaproponował, by kręcić w Pałacu Prasy w Krakowie. Monumentalny budynek w 1972 r. mieścił redakcję „Gazety Krakowskiej" oraz drukarnię; w okresie przedwojennym znajdowała się w nim siedziba koncernu wydawniczego "Ilustrowanego Kuriera Codziennego". Lokalizacja sceny umożliwiła realizację skomplikowaną pod względem inscenizacyjnym - synchronizację ruchu postaci, ujęcia z poruszającej się windy, długie ujęcia kręcone kamerą z ręki. Chwilami operatorowi musiała asystować inna osoba; w momencie, kiedy kamera wchodzi i wychodzi z windy, jest widoczny nawet Grzegorz Królikiewicz prowadzący Bogdana Dziworskiego: Ja Bodzia prowadziłem, miałem baterie, akumulatory w skórzanym pokrowcu, a krótki był przecież kabel do kamery. Byłem z tyłu i trzymałem go za pasek spodni, w ten sposób nakierowywałem. Dziworski jest człowiekiem o gigantycznej intuicji i on tylko by w wspomagany przeze mnie. Byliśmy w przyjaźni artystycznej ${ }^{49}$.

Na początku sceny w wydawnictwie kamera zostawia bohaterkę przy wejściu, powoli tracąc ją z pola widzenia. Jej ruch jest powodowany przez Malisza, który wchodzi do budynku ze swoimi pracami. Jednak kamera nie podąża za bohaterem, przez pewien czas obserwuje go, by w końcu także opuścić, stając się niejako częścią machiny biurokracji - zamiast zgodnie z przyzwyczajeniami widza śledzić bohatera, jedzie winda, błądzi po korytarzach, obserwuje krzątających się ludzi. Jej ruch jest niezgodny z rytmem ruchu zarówno głównych bohaterów, jak i postaci drugoplanowych. To jednak tylko pozorna niezależność, gdyż aparat jest zsynchronizowany z działaniami Malisza. Ruch kamery - rejestrującej początek i koniec poszukiwań pracy - określa rozpiętość czasową wędrówki bohatera. Jednocześnie ruch zarówno samej kamery, jak i Malisza zostaje skonfrontowany ze statycznością Maliszowej, która przez cały czas stoi w tym samym miejscu, jakby 
czekała na ogłoszenie czegoś, co od początku było przesądzone. W finale za plecami pracownika wydawnictwa (Marian Dziędziel) odprowadzającego bohatera widzimy olbrzymi gmach - symbolem jego majestatu jest gryf, godło drukarzy. Jak w takiej przestrzeni miałby odnaleźć się bohater? Niewspółmierność tę podkreśla zniszczony but filmowany z żabiej perspektywy, którym wymachuje zdesperowany Malisz. Kamera obserwuje małżeństwo zza pleców pracownika, jakby byli obcy i niegodni wsparcia.

O ile w scenie w wydawnictwie kamera jest niezależna, zdystansowana wobec głównych bohaterów, o tyle wygląda to zupełnie inaczej w scenie morderstwa staruszków. Tu rzeczywistość widzimy zbyt blisko, i w efekcie zostaje ona zdeformowana. Dominują zbliżenia, eksponowane są detale: zmarszczki, lśniący pot, kula inwalidzka, korzenie rośliny podrygujące niczym w konwulsjach. Kamera często zmienia perspektywę, nerwowy rytm jej ruchu staje się rytmem zbrodni, a jednocześnie podkreśla bezradność Maliszów. Para w niszczycielskim szale usiłuje nie tylko zamordować starszych ludzi, ale i unicestwić otaczającą ich przestrzeń. Realizacja tych ujęć nie byłaby możliwa bez kolejnego wynalazku. Jak wspominał Bogdan Dziworski, zdjęcia makro kręcono za pomocą przejściowych pierścieni. Związany przez lata z łódzką Wytwórnią Filmów Oświatowych operator Stanisław Śliskowski przerobił obiektyw Makro Industar w taki sposób, by można było nim ustawiać ostrość od $1 \mathrm{~cm}$ do nieskończoności ${ }^{50}$. Śliskowski wypożyczył obiektyw na dwa dni do realizacji sceny morderstwa. Był to obiektyw Jupiter wspominał Bogdan Dziworski - od aparatu Zenith. Obiektyw charakteryzowat się podwójnym wyciagiem, więc jednym ruchem ręki mogłem ustawić ostrość na detalu i wrócić do planu ogólnego ${ }^{51}$.

Oglądając uważnie scenę morderstwa, można dostrzec, że w niektórych ujęciach na brzegach kadru widoczna jest kaszeta, wyraźnie zmniejszająca i deformująca jego pole. Ruch kamery w tych ujęciach jest raczej niekonwencjonalny, jakby zdjęcia były realizowane z ukrycia, a nieświadome tego postaci wpadały na aparat. O kulisach powstawania tych ujęć można przeczytać w reportażu z planu filmu: Ostatnie próby z kamera, zmieniła pozycję. Nikt jej w następnym ujęciu nie poprowadzi. Puszczona w ruch nakręci zdjęcia niekontrolowane ludzkim okiem i ręka. W polu jej widzenia rozegra się końcowa faza walki Malisza ze starcem. Wczepieni w siebie przeciwnicy będa się szamotać i przepychać, wpadać na kamerę; ta zaś będzie drgać i tańczyć uwięziona na sprężynach ${ }^{52}$. Po latach Grzegorz Królikiewicz wspominał: Do wynalazku został zbudowany specjalny mechanizm na sprężynach, w środku którego była kamera i można było w nia uderzać i deformować obraz, ona się obracała nie jak u szwenkiera, a mechanicznie $^{53}$. W ujęciach tych urządzenie staje się współuczestnikiem sytuacji, obiektywnym świadkiem mordu, w scenie w wydawnictwie - jak wspomniałem - było zdystansowane do bohatera, tu znajduje się tuż przy postaciach ${ }^{54}$. Jego ruch jest warunkowany walką ofiar z oprawcami. Reżyser komentował to tak: To jest mechanizm - ta zbrodnia jest mechaniczna, jakby samodzielna, ma swoje drgawki, wyzwala się z pracy człowieka ${ }^{55}$.

Swingowanie kamery kończy się w scenie snu morderców podczas ich pobytu w luksusowym hotelu. W finale filmu aparat zamiera, ruch, a wraz nim rytm, który przełamywał przyzwyczajenia widza we wcześniejszych scenach, zanika. Statyczna kamera beznamiętnie rejestruje wydarzenia, nie porusza się nawet, gdy kręcone w bliskich planach postacie znikają poza kadrem. Nietypowe kadrowanie 
jest jak gdyby wynikiem poruszania się bohaterów - zabieg ten powoduje, że ich twarze zostają ucięte. W trakcie zeznań Maliszowej w sądzie widać zaledwie połowę twarzy Malisza, a zamiast twarzy policjantów widzimy tylko ich czapki służbowe. Deformacja postaci staje się jeszcze bardziej wyraźna, kiedy na pierwszym planie ukazuje się duży fragment ławy, a nad głowami bohaterów - zajmująca większą część kadru czarna przestrzeń.

Powrócę jeszcze do koncepcji oświetlenia, która w Na wylot jest również dość odważna i która wywarła duże wrażenie na operatorze Ryszardzie Lenczewskim, gdy jako student Szkoły Filmowej po raz pierwszy oglądał film. Opowiadał: Ciagle nas uczono, że jeżeli scena odbywa się w jakimś miejscu, to powinno się nieustannie kontynuować ten sam nastrój, ten sam rodzaj światta, bo wtedy identyfikujemy się z tym miejscem. W scenie w sadzie kamera stoi frontalnie do bohaterów, wtedy widzimy wyraźnie ich oczy, boczne światło, twarze, ponieważ z tyłu jest ciemne tło wystroju wnętrza. I to jest w porzadku. Potem nagle następuja ujęcia, w których kamera stoi na linii między twarzami a jasnym oknem. Te twarze sa mniej wyraźne, sa właściwie konturem. Najpierw widzieliśmy coś wyraźnego, później mamy niedopowiedzenie. To mnie zafascynowało ${ }^{56}$.

Operatorzy korzystali - jak wspomniałem - z lamp jarzeniowych. Jednak samo oświetlenie nie wystarczyło, by wzmocnić efekt wyizolowania postaci z tła, a zatem Bogdan Dziworski użył jeszcze jednego wynalazku: W scenie na sali sądowej stosowałem w ogólnych planach filtr na podczerwień, to był gęsty filtr czerwony, wtedy nie miałem szczegółów w cieniach tylko kontrast ${ }^{57}$. Statyczność ujęć zostaje tu zakłócona przez wibracje światła, gdy Maliszowie ukazani są w zwolnionym tempie, jak np. w momencie odczytania wyroku czy kiedy małżonkowie próbują zbliżyć się do siebie. Bezruch świata zewnętrznego zestawiony jest z wibracją świata wewnętrznego - sfery duchowej i uczuć bohaterów ${ }^{58}$.

\section{Wieczne pretensje, czyli Bogdan Dziworski po raz drugi}

Wieczne pretensje to drugi film autorstwa duetu Królikiewicz - Dziworski. Akcja filmu rozgrywa się tu i teraz, czyli w rzeczywistości Polski Ludowej połowy lat 70. Rysiek, inspektor kontrolujący zakłady mięsne (Bogusz Bilewski), spotyka na swej drodze złodzieja i nieudacznika Franka (Franciszek Trzeciak) i daje mu szansę na odmianę życia. Ścieranie się postaw bohaterów miało ukazać wartość nadrzędną - ludzką pracę. Rzeczywistość przedstawiona na ekranie nie jest raz na zawsze dana. Wobec tego zadaniem bohaterów jest dopiero podjęcie próby uformowania świata chaotycznego, bezwładnego, budowania go w narastajacym kształcie, w końcu nadania mu scalającej formy ${ }^{59}$ - tłumaczył Grzegorz Królikiewicz. Podobne zadanie reżyser stawia przed widzami, którzy powinni „uformować” świat przedstawiony Wiecznych pretensji.

Uwage przykuwa warstwa wizualna filmu. Obok Bogdana Dziworskiego istotną rolę w jej tworzeniu odegrał Ryszard Lenczewski, którego praca dopełniała znakomicie rytm kamery Dziworskiego. Rysiu byt skupiony, ja byłem rozproszony ${ }^{60}$ - mówił Dziworski. Lenczewski zaś dopowiadał: Królikiewicz uznał, że "Wieczne pretensje" to film, który się składa przynajmniej z dwóch sposobów opowiadania. Jeden $z$ kamery, która jest bardzo intuicyjna, nazwijmy ja umownie rozbrykana; drugi z kamery zaprogramowanej, która powoli, w sposób niezależny, we własnym rytmie opowiada his- 
torię. (...) Taki podział wynikat z decyzji Królikiewicza, on widział takie, a nie inne predyspozycje w nas. Bodzio byt "rozchetstanym" artysta, a ja człowiekiem dopiero startujacym w zawodzie, coś mi się po głowie kołatało artystycznego, ale jednocześnie byłem bardziej zaprogramowany niż Bogdan ${ }^{61}$.

Scena strajku nakręcona w jednym ujęciu
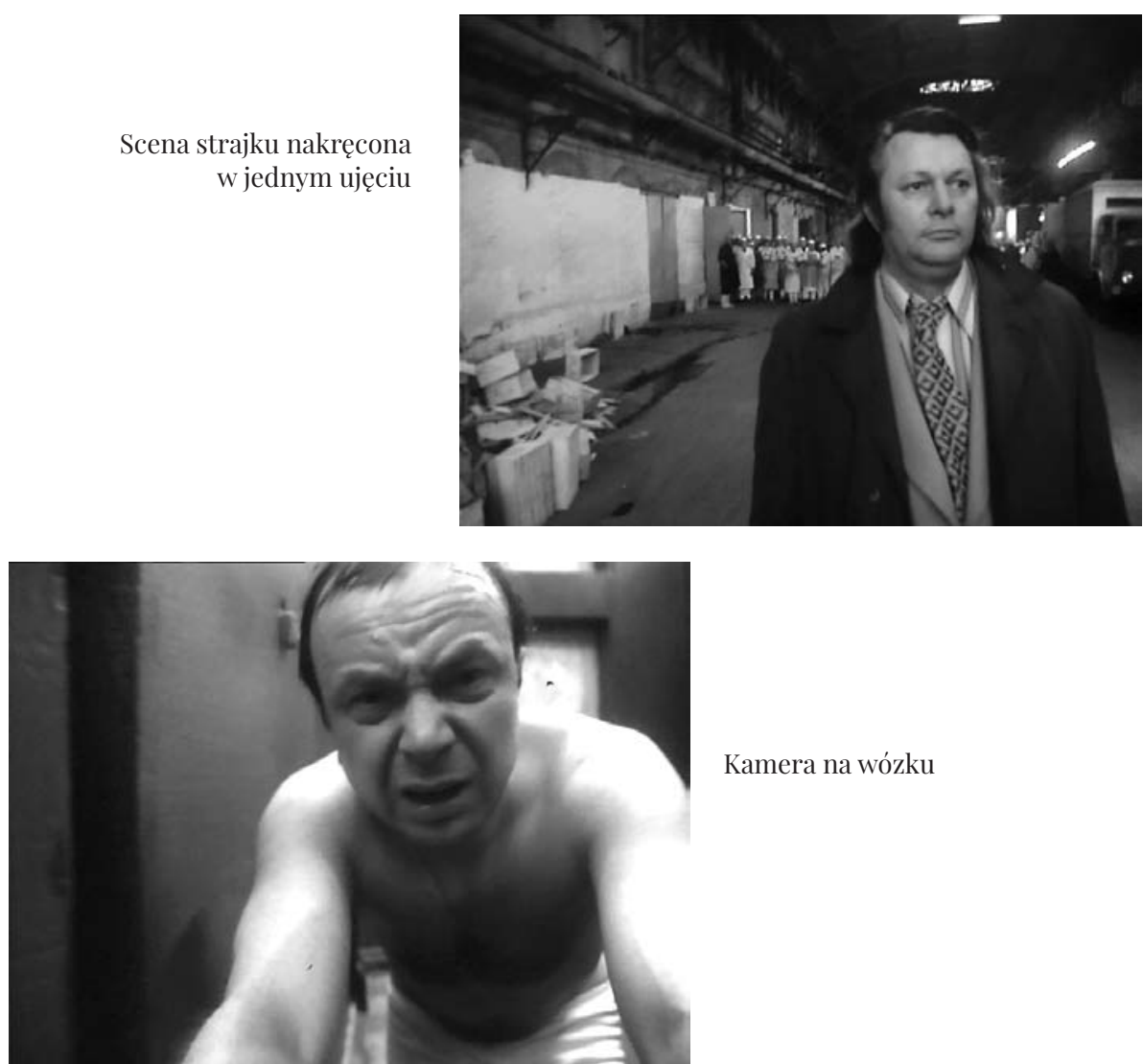

Kamera na wózku

Wieczne pretensje, reż. Grzegorz Królikiewicz (1975)

Wieczne pretensje zrealizowano za pomocą dwóch modeli kamery: Dziworski posługiwał się lekkim Arriflexem IIC, co dawało możliwość realizacji dynamicznych zdjęć z ręki; z kolei statyczne, precyzyjne ujęcia Ryszarda Lenczewskiego kręcone były ciężką kamerą Arriflex 300 z blimpem ${ }^{62}$. Wizualny porządek filmu anonsuje już pierwsza scena. W statycznym ujęciu widzimy wpłynięcie do portu statku pasażerskiego TSS „Stefan Batory”. Lenczewski uchwycił to zdarzenie o wschodzie słońca bardzo długim obiektywem $1000 \mathrm{~mm}^{63}$ : Batory to była scena, która ja nakręciłem, Bodzio był na brzegu. Batorego na morzu kręciłem z wieży, podczas ciepłego światła o świcie ${ }^{64}$. Wspomnienie realizacji tego ujęcia zachowało się także w pamięci Bogdana Dziworskiego: To było idealne szczéście, światło wiele zrobiło, jakby złota dolarówka wptywała, niebywałe ujęcie - odrapany Batory w niesamowitym świetle ${ }^{65}$. Widok nadpływającego powoli statku winien wzbudzać w widzu emocje odczuwane przez stęsknione rodziny, złaknione spotkania z wracającymi zza oceanu bliskimi. Sposób obrazowania zmienia się, gdy oczekująca na nabrzeżu szajka do- 
strzega swoją ofiarę. Kamera prowadzona z ręki nie odstępuje Franka i złodziei, jest bezpośrednim uczestnikiem gorączkowych przygotowań do oszustwa. W pierwszej scenie ruch kamery jest podporządkowany akcji, działaniom bohaterów i podkreśla kontrast między statycznością a dynamizmem. Inaczej rzecz się ma w scenie psychozy Franka. Tu statyczna kamera obserwuje bohatera w laboratorium - mężczyzna wstaje z łóżka, otwiera lodówkę i siada. Po chwili zaczyna się jazda równoległa, kamera jest w pełni autonomiczna, a jej ruchu nie motywuje zachowanie postaci; ustawiona na szynach przemieszcza się wzdłuż ciemnozielonej ściany, na której końcu znajduje się ubikacja. W tej przestrzeni widzimy także Franka, mimo że kamera wcześniej zostawiła go w pomieszczeniu z lodówkami. Mężczyzna otwiera okno i zauważa kochającą się parę. Aparat podgląda go podczas masturbacji do chwili, gdy bohater go spostrzega, chwyta go z krzykiem i pcha do laboratorium. Gdy Franek znika poza kadrem, następuje powolna panorama w kierunku postaci. Końcowy ruch sugeruje ponowne uniezależnienie kamery od bohatera. Realizację sceny zapamiętał fotosista Krzysztof Ptak: To było robione na dwie kamery. Główna do mastershota - Rysiek, ona przejeżdżała z pomieszczenia, gdzie były lodówki, do tego ciemnozielonego. Bodzio Dziworski stał na podwórku z dtugim obiektywem i robił średnie plany kochajacej się pary ${ }^{66}$. Całe ujęcie - wyjaśniał z kolei Ryszard Lenczewski - musiało być bardzo płynne, kamera wędrowała na jeździe, musiała mieć swój własny rytm, swój własny sposób kadrowania, bo wiele rzeczy się dzieje jakby poza kadrem. Trzeba było stworzyć rytm, aktor miat swój, a kamera poruszająca się na wózku swój ${ }^{67}$.

Najbardziej charakterystyczne dla Wiecznych pretensji są długie ujęcia realizowane z ręki, w których wyspecjalizował się Bogdan Dziworski. Przykładem jest tu scena przesłuchania dyrektora rzeźni (Andrzej Lipiński) przez Ryśka. Biernym świadkiem zdarzenia staje się stojący obok samochodu Franek. Prowadzona przez Dziworskiego kamera krąży wokół auta, rejestruje przebieg konwersacji i pozostaje niezależna od obserwacji prowadzonej przez postać. Widz, mimo że - jak Franek i kierowca - śledzi rozmowę z zewnątrz, znajduje się w pozycji uprzywilejowanej, ma bowiem możliwość oglądu sytuacji ze wszystkich stron, ma też dostęp do wydzielonej przestrzeni, nie tylko widzi, ale i słyszy, co dzieje się wewnątrz samochodu. Głębszy sens tego zabiegu wyjaśniał Grzegorz Królikiewicz: Pan chciałby, żeby kamera była statyczna, bo to ułatwia przekaz informacji. Tymczasem ja chce, by film spetniał role polifonicznego, wszechstronnego relacjonowania życia. Ten niepokój kamery dodawat do rozmowy kontrolera sprawe odczuć Franka (...), który analizowat swoja role w tym konflikcie, byt pełen niepokoju. To on doprowadzit dyrektora, a teraz nawet nie wie, o czym tam w samochodzie rozmawiaja te dwa olbrzymy ${ }^{68}$.

Najdłuższym ujęciem w Wiecznych pretensjach jest to, w którym został ukazany strajk w rzeźni. W latach 70. długie ujęcie kamerą z ręki było nie tylko ewenementem stylistycznym, dużym osiągnięciem operatorskim, ale i innowacją techniczną. W przypadku filmu Królikiewicza kamera Arriflex została umieszczona na nosidle, które opierało się na ramieniu operatora, z tyłu zamocowane zostały akumulatory zasilające. Opracowanie technicznej części wynalazku zlecono inżynierowi Jerzemu Sankowskiemu z Wytwórni Filmów Fabularnych we Wrocławiu $^{69}$. Asystent operatora obrazu Stefan Kurzyp wspominał: Bodzio powiedziat - potrzebuje mieć kamerę w ręku i sterować nią. Moge mieć do dyspozycji tylko Arriflexa ręcznego, ale panie inżynierze, niech pan zaprojektuje go tak, żeby unióst kasete 
300-metrowa. Prosze wymyślić nosidło, żebym oparł kamerę na ramionach, a z tyłu dla przeciwwagi, żeby były dwa akumulatory. Sankowski zaprojektowat, jak sobie Bodzio wymyślit. Jeden akumulator zasilał kamerę, drugi silnik kasety. Do wejścia kasety Arriflexa zbudował napęd kasety odbiorczej, żeby nawijała się taśma, która szła z nadawczej. Sankowski wszystko wyrysowat, wykonat projekt, zrobit próbę $i$ znakomicie zadziałało ${ }^{70}$. Krzysztof Ptak opisywał to tak: Bodzio Dziworski bił rekordy, robił z ręki w rzeźni we Wrocławiu długie ujęcie na dużych przestrzeniach. To była kamera Arri 2C z kaseta 300-metrowa. To był wyczyn fizyczny, kamera ważyła, była niewygodna. Ogromna kaseta dawała możliwość nakręcenia 10-minutowego ujęcia ${ }^{71}$; sam Dziworski zaś mówił: 300 metrów... bardzo się nad tym napracowałem. Było dość ryzykownie. Człowiek od BHP, który przyszedł na plan, przestrzegat, że nie radzi robić tego ujęcia ze względu na ciężar kamery i kregostup. To była kamera skompilowana z kaseta 300, ciężk rzecz. Zrobiłem to ujęcie - dwa duble, ale Królikiewicz je skrócit, w filmie zostało może 200 metrów $w^{72}$.

W opisywanym ujęciu kamera towarzyszy ubranym w białe stroje mężczyznom, zgromadzonym w gabinecie dyrektora. Po chwili opuszcza ich, skupiając się na stojącym w pomieszczeniu Ryśku, luksusowych tapetach, suficie z pałacowym żyrandolem. Jej ruch zostaje zestawiony z zamarciem strajkujących mężczyzn, którzy niczym posągi tkwią w rzędzie przed dyrektorem. Rysiek zajmuje uprzywilejowaną pozycję - staje przed strajkującymi, zasłaniając swoim ciałem dyrektora i symbolicznie biorąc odpowiedzialność za prowadzące do buntu zachowanie Franka. Inspektor wymienia spojrzenie ze stojącym na czele tłumu mężczyzną. Mimo braku sygnałów o rozstrzygnięciu sporu kamera wycofuje się, zostawiając postacie w gabinecie; po chwili mija grupę mężczyzn, którzy opuścili pomieszczenie i biegną do znajdujących się w hali kobiet. Bogdan Dziworski mówił o tej scenie: To też jest czesść przestrzeni pozakadrowej, nie tylko wprost jedziemy kamera za aktorem, ale wymijamy, jedziemy $w$ druga strone, wyprzedzamy, cofamy się ${ }^{73}$.

W tym samym fragmencie zostało ukazane zakończenie strajku. Rysiek wręcza goździki kobietom ustawionym w szpaler, całuje je w rękę, rekompensując w ten sposób zachowanie Franka, i tłumi bunt. Kobiety wychodzą z hali, rytm kamery jest niespokojny. Gdy przyjeżdża służbowy samochód Ryśka, aparat zagląda do bagażnika, w którym znajdują się naręcza kwiatów. Kiedy bohater odwraca się tyłem do stojących na dziedzińcu mężczyzn, kamera podąża w ich kierunku, agresywnie zbliżając się do ich twarzy, jakby jej nerwowość miała zrekompensować bierność pracowników rzeźni. Scena zainscenizowana została bez użycia słów, a środkami mającymi wyrazić emocje strajkujących są tylko kamera, rytm filmowania, sposób kadrowania i muzyka ilustracyjna. W ten sposób, w jednym, trwającym ponad 6 minut ujęciu, Królikiewicz ukazał historię buntu - od wybuchu do jego zdławienia ${ }^{74}$.

\section{Tańczacy jastrzab i eksperymenty Zbigniewa Rybczyńskiego}

Grzegorz Królikiewicz powiedział kiedyś: Świat filmu dzieli się dla mnie na świat sfotografowany (odwołujacy się do swoistej rytmiki tej sztuki) oraz świat nazwy (gtupkowate obrazy, adaptacje literatury albo malarstwa). Jedynym operatorem żyjacym jest Dziworski, a reszta to trupy ${ }^{75}$. Deklaracja reżysera przestała być aktualna, gdy do produkcji skierowano jego trzeci film fabularny i kiedy okazało się, że autorem 
zdjęć będzie Zbigniew Rybczyński. Ten 27-letni absolwent Szkoły Filmowej miał już na swoim koncie zdjęcia do filmów krótkometrażowych Andrzeja Barańskiego, Piotra Andrejewa i Wojciecha Wiszniewskiego; zrealizował także w łódzkim Se-Ma-Forze filmy eksperymentalne (Oj! Nie mogę się zatrzymać oraz Nowa ksiażkęoba w 1975 r.). To właśnie pod ich wpływem Królikiewicz zdecydował się powierzyć mu autorstwo zdjęć do Tańczącego jastrzębia, filmu o życiu chłopa Michała Topornego (Franciszek Trzeciak), który porzuca wieś, by za wszelką cenę zrobić karierę w mieście. Pomyślałem, że jest to człowiek [Rybczyński], który w idealny sposób wyczuje ideę przejścia z matecznika w industrię. Matecznik łatwiej sfotografować niż industrię, w uprzemysłowieniu jest ogromna ilość pośredników i zapośredniczeń, często można się zgubić w opisaniu tego $o^{76}$ - opowiadał Królikiewicz. Gdy reżyser zaproponował Rybczyńskiemu współpracę, ten znał już Na wylot, o którym mówił, że jest to arcydzieło, niesamowity film ${ }^{77}$. Pomimo zachwytu nad debiutem Królikiewicza po przeczytaniu scenariusza Tańczącego jastrzębia filmowiec odmówił współpracy i zmienił zdanie dopiero, gdy uzyskał zapewnienie o zmodyfikowaniu projektu filmu zgodnie $\mathrm{z}$ jego pomysłami ${ }^{78}$. Prace nad scenariuszem trwały kilka miesięcy. W tym czasie powstał scenopis oraz rysunki z projektami wynalazków, które Rybczyński chciał wykorzystać przy realizacji filmu. Tańczący jastrząb powstał w łódzkiej Wytwórni Filmów Fabularnych i to tam oddelegowano zespół techniczny, mający zbudować zaprojektowane konstrukcje ${ }^{79}$. Operator otrzymał do dyspozycji także nowość techniczną - lekką kamerę Arriflex 35BL II ${ }^{80}$ umożliwiającą synchroniczne rejestrowanie obrazu i dźwięku.

Zdjęcia do Tańczacego jastrzębia rozpoczęły się jesienią 1976 r. i już wkrótce okazało się, że wiele eksperymentalnych pomysłów Rybczyńskiego nie zostanie zrealizowanych. Operator zapamiętał jedną z rozmów z reżyserem: Zbyszek, to, co żeśmy wymyślili, to jest malarstwo zachodnioeuropejskie, zapomnij o wszystkim, twoim zadaniem jest skupienie się na twarzy Franciszka Trzeciaka - powiedziat Królikiewicz. Jak to? Nie będzie naszych pomysłów i konstrukcji? - zapytałem. Twarz Trzeciaka, Zbyszku! ${ }^{81}$ Na przykład w scenie, w której chłopi dzięki reformie rolnej dostają przydział ziemi, zaplanowane było ujęcie Michała Topornego przerzucającego kamień z ręki do ręki. Kamień ten miał stawać się coraz większy do chwili, gdy byłby już nie do udźwignięcia ${ }^{82}$. Mimo atrakcyjności pomysłu reżyser go odrzucił³. Jeszcze bardziej widowiskowa miała być scena, w której chłop Kinol (Józef Fryźlewicz), broniąc brzozowego lasku przed wycinką, siekierą obcina głowę robotnikowi (Wirgiliusz Gryń). Nakręcenie jej nie byłoby problematyczne, gdyby nie fakt, że chciano to zrobić z perspektywy odciętej, toczącej się głowy, która na koniec wpada do wody $^{84}$. Jak wspominał scenograf Bogdan Mozer: Zrobiłem więc "głowę" - kapsułe z otworem na obiektyw umieszczony wewnątrz kamery, z mechanizmem umożliwiajacym jej uruchomienie, dodatkowo odporna na wstrząsy $i$ wodoszczelną ${ }^{85}$. Scenę nagrano, jednak Grzegorz Królikiewicz zrezygnował potem z pierwotnego pomysłu. W ostatecznej wersji morderstwo dokonuje się w przestrzeni poza kadrem, a śmierć robotnika symbolizuje zakrwawiona siekiera wbita w dno źródełka.

Przykłady te tłumaczą zasadę wizualna, której podporządkowany jest świat przedstawiony w Tańczącym jastrzębiu. Dzięki autonomiczności kamery uniemożliwiona zostaje identyfikacja $\mathrm{z}$ bohaterami filmu, widz patrzy na wydarzenia z boku, obserwuje je z nietypowych perspektyw. W scenie ukazującej morderstwo robotnika kamera miała uchwycić moment, w którym żywy człowiek zamienia się 
w martwe ciało, z kolei scena rozgrywająca się we wrześniu 1939 r. sfilmowana została z perspektywy zranionego ramienia żołnierza. W celu nakręcenia tego ujęcia powstała konstrukcja nazwana „kamerą z ranną ręką”. Rybczyński odnotował: Kamerę zawieszono na atrapie ręki przez palce wskazujacy i mały, które obejmują obiektyw i sa poza polem widzenia obiektywu ${ }^{86}$. Punktem kulminacyjnym ujęcia jest pozbawienie żołnierza ręki przez Topornego za pomocą nożyc do strzyżenia owiec. Aby tego dokonać, odcięto zamocowaną na szelkach atrapę ręki, tak by upadła - wraz z nieustannie pracującą kamerą - na leżącą na ziemi pierzynę.

Pomysłowości wymagała również scena wybuchu wojny zrealizowana z perspektywy szarżującego byka. Można dostrzec, że kamera została umieszona za rogami zwierzęcia. Zbigniew Wichłacz wyjaśniał: Zrobiliśmy specjalna uprzaż na końskim siodle. Kamerę wzięliśmy z wytwórni, ledwo dychała, ale była sprawna i gwarantowała ostrość. Byk zachowywat się spokojnie, ale nadleciał helikopter, wytworzył hałas $i$ tumany kurzu, a on oszalat. $O$ to chodziło ${ }^{87}$. Wybuch wojny ukazany symbolicznie za pomocą biologicznej reakcji zwierzęcia na zagrożenie miał być zestawiony z obrazem maszynerii wojennej. Koniec okupacji, a zarazem pojawienie się w życiu Michała Topornego oznak nowoczesności zwiastował czołg wkraczającej do Polski Armii Czerwonej. Jak wspominał Zbigniew Rybczyński: Miało być dramatycznie. Szukaliśmy sposobu, jak pokazać ich siłe, i wpadłem na pomyst, żeby przymocować kamere do gąsienicy czołgu, żeby jej nie zniszczyć. Okazało się, że najlepszym rozwiazaniem było przyspawać koziołek zamontowany do kamery. I żeśmy coś takiego zrobili, czołg wjechat $w$ brzozowy las $i$ było widać, jak drzewa się łamia, a kamera obraca się do góry nogami ${ }^{88}$. Także ta scena nie znalazła się w ostatecznej wersji filmu ${ }^{89}$.

Istotnym elementem konstrukcji narracyjnej Tańczacego jastrzębia jest powtarzalność motywów. Pojawiają się one w różnych wariantach, służąc przedstawieniu dwóch okresów z życia Topornego - wiejskiego i miejskiego. W jednej z początkowych scen została ukazana śmierć matki głównego bohatera, fragment ten wmontowany jest w ciąg ujęć ukazujących Topornego, który prowadzi zaprzęgniętego do kieratu konia. Kamera została tu zamocowana na stalowym kole, jakby była częścią maszyny rolniczej. Ruch okrężny powraca, gdy Michał Toporny ma nowa miejską rodzinę. W jednej ze scen Wiesława, druga żona bohatera (Beata Tyszkiewicz), wraz z matką i ojcem debatuje nad zachowaniem Michała. Tym razem kamera została ustawiona pod łóżkiem, tak że widz ogląda zdarzenie z perspektywy kogoś, kto się pod nim chowa. Aparat wykonuje dwa pełne obroty, a przed rozpoczęciem kolejnego następuje cięcie montażowe. W kadrze widzimy kolorową piłkę ${ }^{90}$, zeschnięte jabłko, nocnik oraz nogi rozmawiających domowników. Płynność toczącej się rozmowy zostaje skontrastowana z obrazem - w trakcie obrotu kamery z kadru znika nocnik, na którym posadzono znajdującego się już poza kadrem syna Michała i Wiesławy. Cały zabieg trwa raptem 30 sekund (jeden obrót kamery). Zachodzi tu więc rozdźwięk między realnym czasem rozmowy a czasem potrzebnym, by zaszło to, co widoczne w kadrze. Do realizacji tak zaplanowanego ujęcia konieczny był wynalazek Zbigniewa Rybczyńskiego: Zbudowałem ręcznie obracana korbę, na zewnątrz łóżka wycięliśmy dziurę w materacu, siedziałem na tóżku i kręciłem kamera zamontowana na obrotowym łożysku. W filmie było dużo obrotów ${ }^{91}$. Warto zatem zadać pytanie: kto obraca tym miejskim kieratem? O ile w przypadku pracy na wsi - maszynę rolniczą napędzał wysiłek człowieka i zwierzęcia, o tyle - w wariancie miejskim - relacja ta nie jest jednoznaczna: machina 
jest zsynchronizowana z rytmem życia rodzinnego Wiesławy, a elementem obcym, asynchronicznym jest nieobecny w kadrze Toporny. Reprezentacją tej nieobecności jest nieprzyjemny dźwięk słyszalny w końcowej fazie ruchu kamery, zwiastujący "awarię" w życiu rodziny.

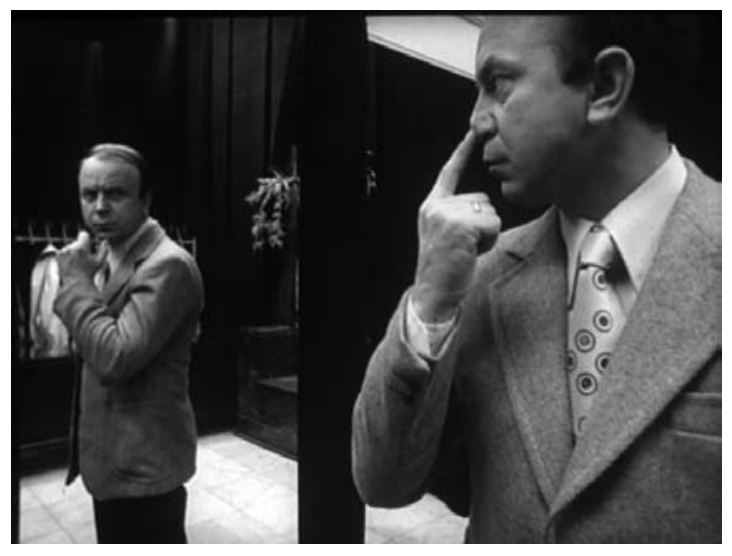

Asynchroniczne odbicie w lustrze

Kamera z perspektywy odciętej ręki
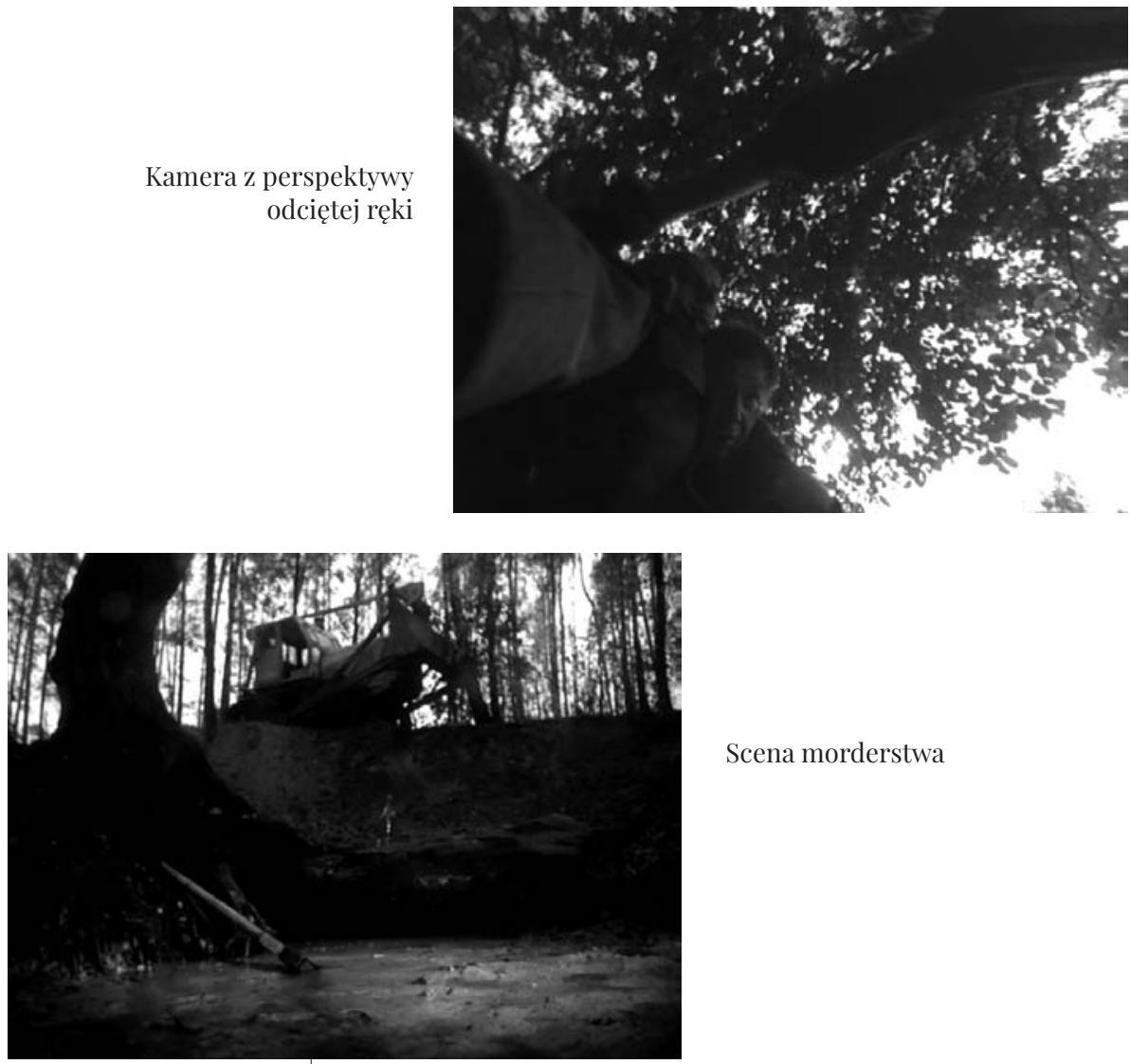

Scena morderstwa

Tańczacy jastrzab, reż. Grzegorz Królikiewicz (1978) 
Świecące ucho Michała Topornego
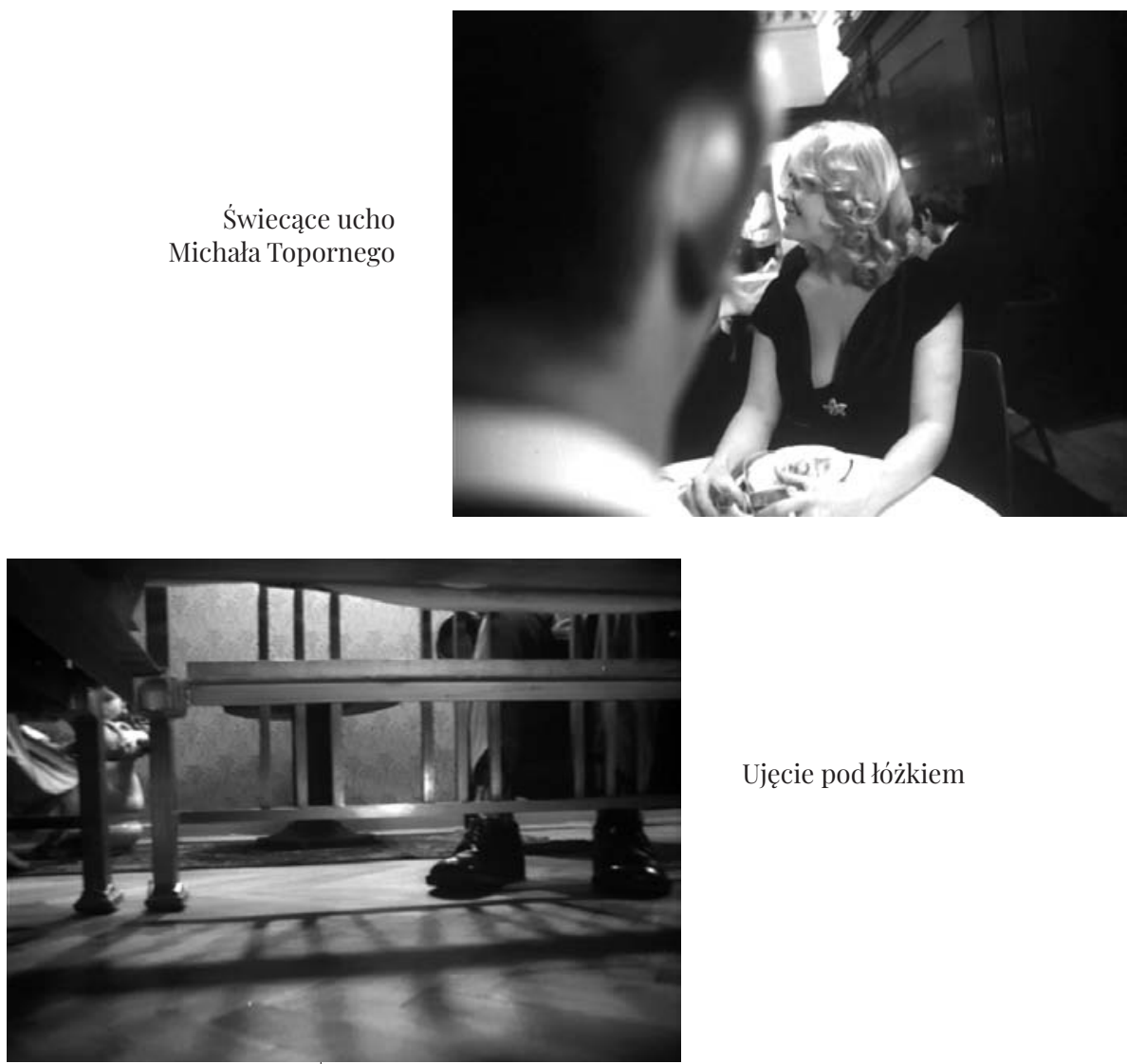

Ujęcie pod łóżkiem

Tánczacy jastrzą, reż. Grzegorz Królikiewicz (1978)

Pęknięcie między życiem wiejskim i miejskim obecne jest także w samym Topornym, który niepewny swojej tożsamości, regularnie stara się ją zweryfikować. Motywem wielokrotnie pojawiającym się w filmie jest lustro. Podczas balu podyplomowego Michał idzie do szatniarza, by kupić papierosy, po drodze zderzając się ze swoim odbiciem w lustrze. Spojrzenie na siebie to moment weryfikacji - Toporny skończył studia, poznał atrakcyjną kobietę, jest u progu nowego życia. W kolejnym ujęciu przed lustrem Toporny ubrany jest już w inny garnitur, nową skórę, jednak jego odbicie jest asynchroniczne - bohater prostuje zadarty nos, zaczesuje przerzedzone włosy, pucuje o nogawki garnituru buty; zdaje się zahipnotyzowany swoim wizerunkiem ${ }^{92}$. Nakręcenie tej sceny $w$ realiach produkcji filmowej w PRL nie było łatwe. Jak podkreślał Zbigniew Rybczyński: W Polsce nie było kopiarki optycznej stużącej do przeróbki materiału filmowego, dlatego efekty specjalne robiliśmy w kamerze. Ekran był podzielony na dwie części, na obiektywie była kaszeta, taka zasłonka. Najpierw filmowałem pót obrazu, potem przewijatem taśmę z powrotem, odsłaniałem druga część kadru i nagrywałem jego prawa czesść. Wszystko trzeba było dobrze wyciemnić, żeby nie powstawały refleksy na stronach kadru. Musiałem zadbać o wiele rzeczy, wsadzić taśmę w odpowiednia perforację, przewinać taśmę w ciemności, oznaczyć start nacięciem na taśmie, wyliczyć, kiedy i jakie Franciszek Trzeciak wykonywał ruchy ${ }^{93}$. 
Przykładem włączenia technologii w diegezę są natomiast monitory ukazujące obraz z kamer przemysłowych. Ekrany pełnią funkcję luster, w których przegląda się Toporny. Tu także istnieje pewien rozdźwięk między widokiem biegnącego korytarzem bohatera a jego obrazem na monitorze, wskazującym, że mężczyzna jest zmęczony i porusza się z trudem. Obraz Topornego powraca w późniejszej części filmu; nie wiadomo, ile czasu minęło, jednak oznaką jego upływu jest fizyczna metamorfoza bohatera - na jednym z monitorów widać go takim, jakim chciałby być albo był kilka lat temu, drugi monitor pokazuje przedwcześnie postarzałego mężczyznę, który z trudem łapie oddech. Zwodniczość obrazu na monitorze pokazującym siłę i witalność została podkreślona zabiegiem audialnym - na ścieżce dźwiękowej słychać nienaturalnie głośne kroki mężczyzny, które miały brzmieć jak u kolosa, olbrzyma ${ }^{94}$. Ten „,fałszywy” obraz bohatera widać też na ekranie monitora w gabinecie dyrektora (Tadeusz Łomnicki) nadzorującego pracę Topornego.

Opis wynalazków i eksperymentalnych pomysłów Zbigniewa Rybczyńskiego oraz Grzegorza Królikiewicza byłby niepełny bez wskazania surrealistycznych koncepcji, które odnoszą się do początku i końca edukacji bohatera. Inicjacja Topornego w obcym, miejskim świecie odbywa się w stołówce studenckiej. Moment ten opisywał Mirosław Przylipiak: Chcac np. sportretować wielokrotnie już w kinie pokazywane uczucie obcości towarzyszace człowiekowi, który znalazł się w całkiem nowym środowisku, [operator] osiaga to w "Tańczacym jastrzębiu” świetna trickowa scena... jedzenia makaronu. Siedzacy w stołówce Toporny ze zdumieniem patrzy, jak jego sasiad wsysa i na powrót wypuszcza nitki makaronu, niczym żmija cienki, rozwidlony język $k^{95}$. W tym celu Rybczyński założył taśmę 35 mm odwrotnie - jak tłumaczył Wichłacz: Taśma w kasecie nawijała się do tyłu, była przewinięta ze szpuli odbierającej w kamerze, biegła do tyłu i nawijała się na druga rolke, która normalnie jest rolka poda$j a c a^{96}$. Równie ciekawy zabieg pojawia się w momencie, gdy Toporny kończy studia. W trakcie podyplomowego balu Wiesława interesuje się absolwentem, co go peszy - formalnie jest on już innym człowiekiem, jednak wciąż czuje się niepewnie. Oznaką emocji mężczyzny jest czerwieniejące z wrażenia ucho, to samo, za które ciągnął go w dzieciństwie ojciec. Jak w przypadku innych pomysłów Zbigniewa Rybczyńskiego, realizacja tego również nie była łatwa. Przygotowania relacjonowała recenzentka czasopisma „Film”: Prosty zabieg: scena rozmowy Wiesławy i Michała będzie filmowana zza pleców mężczyzny - na kobietę. Przez zaczerwienione z emocji ucho Michała. Ważne to ucho, zdradza emocje, zadaje kłam spokojnym, na pozór obojętnym, opanowanym słowom. "Ale jak to zrobisz - niepokoi się Trzeciak - jak to podświetlisz, w ucho mi żarówkę wkręcisz? To raczej niech mi je na czerwono ucharakteryzuja". (...) Będzie maleńka żarówka połaczona z bateryjka ukryta w kieszeni garnituru. W odpowiedniej chwili charakteryzator przymocuje ja do wewnętrznej strony ucha aktora. Próbuja. Operator Zbigniew Rybczyński jest zadowolony. Kamera widzi efekt zgodny z zamierzeniami ${ }^{97}$. Operator wspominał po latach: Trzeciak miał wsadzonq do ucha żaróweczkę. To nie było proste, bo z bateriami były ciężkie czasy i wówczas nie było czułych negatywów. Myśmy to kręcili na taśmie standard Eastman Kodak i do tego musiało być mocne światło, by podświetlenie było widoczne ${ }^{98}$. Zabieg został dostrzeżony i wywołał żywą reakcję $\mathrm{w}$ trakcie specjalnego pokazu filmu. Zbigniew Wichłacz opowiadał: Była projekcja w Szkole Filmowej. Królikiewicz film przywiózł, chciał pokazać, co zrobit, a w trakcie projekcji reżyser Marek Koterski krzyczał na cała sale „zgaśta mu to ucho"99. 
$\mathrm{Na}$ wylot, Wieczne pretensje i Tańczacy jastrząb tworzą tryptyk ${ }^{100}$, którego wspólnym elementem jest klęska, jaką ponoszą główni bohaterowie: niespełniony artysta Jan Malisz, złodziejaszek Franek oraz chłop Michał Toporny (we wszystkie postacie wcielił się Franciszek Trzeciak). Królikiewicz przedstawił warianty losu człowieka - mężczyzny żyjącego w czasach II Rzeczypospolitej, latach 70. oraz okresie powojennych przemian społecznych. Filmy te łączą rozwiązania techniczne, jak np. oświetlenie jarzeniowe czy specjalne kolby umożliwiające realizację długich ujęć kamerą z ręki. Technologicznym poligonem doświadczalnym była realizacja Tańczacego jastrzębia, choć niemożność pogodzenia idei z rzeczywistością doprowadziła do rezygnacji z części koncepcji, a nawet do wycięcia niektórych ujęć w fazie montażu. Mimo tych ograniczeń dzieło duetu Królikiewicz - Rybczyński jest ewenementem w historii kina polskiego. Jak podkreślał autor nagrodzonego kilka lat później Oscarem Tanga (1980): To, co planowaliśmy w sferze obrazu, było wielkim novum, wiele konstrukcji, które chciatem tam stworzyć, potem budowałem i rozwijałem w swoich filmach w Stanach ${ }^{101}$. Nie ulega wątpliwości, że historia polskiej kinematografii winna zostać uzupełniona o badania dotyczące jej wymiaru technologicznego. Dobrym asumptem do ich podjęcia jest postępujący proces cyfrowej rekonstrukcji dzieł filmowych.

${ }^{1}$ Rozmowa M. Dondzika z Bogdanem Dziworskim, 12 maja 2016, Archiwum Michała Dondzika (dalej AMD).

${ }^{2}$ Rozmowa M. Dondzika ze Zbigniewem Rybczyńskim, 4 października 2020, AMD.

${ }^{3}$ M. Wojciechowski, Pragne wyzwolić niepokój egzystencjalny - z Grzegorzem Królikiewiczem rozmawiał Mikołaj Wojciechowski, "Ekran” 1972, nr 30, s. 16.

${ }^{4}$ Fragment z wypowiedzi Grzegorza Królikiewicza podczas spotkania, które odbyło się w łódzkim kinie Charlie 11 marca 2015, AMD.

${ }^{5}$ Bogdan Dziworski był autorem zdjęć do bułgarskiego filmu partyzanckiego pt. Do ostatniego tchu w reżyserii Griszy Ostrowskiego.

${ }^{6}$ Rozmowa M. Dondzika z Bogdanem Dziworskim, 12 maja 2016, AMD.

7 Tamże.

${ }^{8}$ M. Wojciechowski, Pragne, wyzwolić niepokój egzystencjalny... dz. cyt., s. 16.

9 Rozmowa M. Dondzika ze Zdzisławem Kaczmarkiem, 19 maja 2016, AMD.

${ }^{10}$ Model ten widoczny jest na zachowanych werkach do filmu. Zob. zdjęcia o sygnaturach 1-F-489-133 oraz 1-F-489-171 dostępne na stronie http://fototeka.fn.org.pl/ (dostęp: 11.03.2021).

${ }^{11}$ Por. Ustugi wydziału techniki zdjęciowej. Szczegółowy plan filmu „Sprawa Maliszów” 1972, sygn. 1/543, zesp. WFF w Łodzi, Archiwum Państwowe w Łodzi, s. 14.
${ }^{12}$ Rozmowa M. Dondzika z Grzegorzem Królikiewiczem, 22 sierpnia 2017, AMD.

${ }^{13}$ Fragment wstępu Grzegorza Królikiewicza do filmu Na wylot, Kino Polska, 2004.

${ }^{14} \mathrm{~S}$. Mamber, Cinéma-vérité: Studies in Uncontrolled Documentary, MIT Press, Cambridge 1974, s. 2-4. Cyt. za: M. Przylipiak, Kino bezpośrednie. 1960-1963, słowo/obraz terytoria, Gdańsk 2007, s. 15-16.

${ }^{15}$ Fragment wstępu Grzegorza Królikiewicza do filmu Na wylot, dz. cyt.

16 Dokładnej analizy tej sceny dokonuje M. Przylipiak, Kino bezpośrednie... dz. cyt., s. 76-77.

${ }^{17}$ Fragment wstępu Grzegorza Królikiewicza do filmu Na wylot, dz. cyt.

18 Tamże.

${ }^{19}$ Rozmowa M. Dondzika z Grzegorzem Królikiewiczem, 22 sierpnia 2017, AMD.

${ }^{20}$ Rozmowa M. Dondzika z Jerzym Wrońskim, 1 lutego 2017, AMD.

${ }^{21}$ Rozmowa M. Dondzika ze Zdzisławem Kaczmarkiem, 19 maja 2016, AMD.

${ }^{22}$ Rozmowa M. Dondzika z Bogdanem Dziworskim, 12 maja 2016, AMD.

${ }^{23}$ Rozmowa M. Dondzika z Grzegorzem Królikiewiczem, 22 sierpnia 2017, AMD.

${ }^{24}$ Tamże.

${ }^{25}$ Rozmowa M. Dondzika z Bogdanem Dziworskim, 12 maja 2016, AMD.

${ }^{26}$ Fragment wstępu Grzegorza Królikiewicza do filmu Na wylot, dz. cyt. 
${ }^{27}$ T. Kłys, Od Mabusego do Goebbelsa. Weimarskie filmy Fritza Langa i kino niemieckie do roku 1945, Wydawnictwo Uniwersytetu Łódzkiego - Wydawnictwo Biblioteki PWSFTviT, Łódź 2013, s. 23-36.

${ }^{28}$ P. Kletowski, P. Marecki, Królikiewicz. Pracuje dla przyszłości, Korporacja Ha!Art, Kraków 2011, s. 55.

${ }^{29}$ Sprawozdanie z wykonania planu kosztów filmu, Z.F. Silesia. Filmy zrealizowane $\mathrm{Na}$ wylot 1972-1973, Przedsiębiorstwo Realizacji Filmów Zespoły Filmowe, Archiwum Państwowe w Warszawie, Wieloosobowe Stanowisko ds. Działalności Archiwalnej w Milanówku (dalej jako APDOiP), sygn. 945, k. 41.

${ }^{30}$ Rozmowa M. Dondzika z Bogdanem Dziworskim, 12 maja 2016, AMD.

${ }^{31} \mathrm{M}$. Wojciechowski, KOTF wykonuje po prostu swoje obowiazki... - z Wiesławem Stemplem rozmawiał Mikołaj Wojciechowski, „Ekran” 1971, nr 34, s. 5.

32 Rozmowa M. Dondzika z Bogdanem Dziworskim, 12 maja 2016, AMD.

${ }^{33}$ Zgodnie z powszechnym trendem nastapit przełom na rzecz filmu barwnego - z 22 filmów roku 1969 barwnych było 7, z 20 filmów polskich, które weszty na ekrany w roku 1972, tylko 5 było czarno-białych (...); w kwietniu 1973 roku wśród filmów oczekujących na premiery, realizowanych lub skierowanych do realizacji, byty 24 barwne $i$ jeden czarno-biały (debiut) - pisała recenzentka „Kina”. W. Wertenstein, Móc, chcieć, wiedzieć i zdążý, „Kino” 1973, nr 7, s. 22. W latach 80. polscy filmowcy powrócili do realizacji filmów na taśmie czarno-białej. Piotr Andrejew nakręcił Czułe miejsca (1980), a Janusz Zaorski Matkę Królów (1987).

34 S. Janicki, Poza kadrem - z Grzegorzem Królikiewiczem rozmawiał Stanisław Janicki, „Kino” 1973, nr 4, s. 8.

35 Rozmowa M. Dondzika z Grzegorzem Królikiewiczem, 22 sierpnia 2017, AMD.

36 A. Zarzycki, Rozpacz i zbrodnia, "Magazyn Filmowy" 1972, nr 31, s. 11.

37 Rozmowa M. Dondzika ze Zdzisławem Kaczmarkiem, 19 maja 2016, AMD.

${ }^{38}$ Wynalezione przez Bogdana Dziworskiego lampy jarzeniowe można zobaczyć na werkach do filmu. Zob. zdjęcia o sygnaturach: 1-F-489-33, 1-F-489-125, 1-F-489-108 dostępne na stronie http://fototeka.fn.org.pl/ (dostęp: 11.03.2021)

39 Rozmowa M. Dondzika z Bogdanem Dziworskim, 12 maja 2016, AMD.

${ }^{40}$ S. Janicki, Poza kadrem... dz. cyt., s. 8.

${ }^{41}$ Tamże, s. 9.
${ }^{42}$ Filmem, który rozsławił w Polsce steadicam, było Lśnienie (The Shining, reż. Stanley Kubrick, 1980), specjalny pokaz odbył się w Szkole Filmowej w Łodzi.

${ }^{43}$ Rozmowa M. Dondzika z Bogdanem Dziworskim, 12 maja 2016, AMD.

44 Tamże.

${ }^{45}$ Tamże.

${ }^{46}$ Tamże.

${ }^{47}$ Zob. G. Królikiewicz, Sprawa Maliszów. Scenopis, Zespół Realizatorów Filmowych Silesia, s. 25-26, S-12785, Archiwum Filmoteki Narodowej - Instytutu Audiowizualnego.

${ }^{48}$ Rozmowa M. Dondzika z Grzegorzem Królikiewiczem, 22 sierpnia 2017, AMD.

${ }^{49}$ Tamże.

${ }^{50}$ Rozmowa M. Dondzika ze Stanisławem Śliskowskim, 16 października 2017, AMD.

51 Rozmowa M. Dondzika z Bogdanem Dziworskim, 12 maja 2016, AMD.

52 Adam Zarzycki, dz. cyt., s. 11.

${ }^{53}$ Rozmowa M. Dondzika z Grzegorzem Królikiewiczem, 22 sierpnia 2017, AMD.

54 Wykonanie "specjalnego urządzenia przy statywie kamery" przez Wydział Mechaniczny w WFF w Łodzi kosztowało 1605 zł. Sprawozdanie z wykonania planu kosztów filmu, Z.F. Silesia. Filmy zrealizowane "Na wylot" 1972-1973, Przedsiębiorstwo Realizacji Filmów Zespoty Filmowe, APDOiP, sygn. 945, k. 37.

${ }^{55}$ Rozmowa M. Dondzika z Grzegorzem Królikiewiczem, 22 sierpnia 2017, AMD.

${ }^{56}$ Rozmowa M. Dondzika z Ryszardem Lenczewskim, 3 maja 2016, AMD.

${ }^{57}$ Tamże.

${ }^{58}$ Jak wynika ze wspomnień Bogdana Dziworskiego, pomysł na wibrację światła powstał z powodu usterki technicznej oświetlenia jarzeniowego. Kiedy kręciłem na dużej ilości klatek na sekundę i jarzeniówka nie wytrzymywała, zaczynała drgać, w zasadzie to był bład, ale Królikiewicz takie błędy łapał w lot i przekuwał w złoto - wspominał operator. Rozmowa M. Dondzika z Bogdanem Dziworskim, 12 maja 2016, AMD.

59 A. Markowski, Formowanie chaotycznego świata - z Grzegorzem Królikiewiczem rozmawiat Andrzej Markowski, „Kino” 1975, nr 7, s. 14 .

${ }^{60}$ Rozmowa M. Dondzika z Bogdanem Dziworskim, 12 maja 2016, AMD.

${ }^{61}$ Rozmowa M. Dondzika z Ryszardem Lenczewskim, 3 maja 2016, AMD.

${ }^{62}$ Miałem być człowiekiem - opowiadał Ryszard Lenczewski - który kręci przy pomocy korbek bardzo delikatnie prowadzona kamera. Nigdy takiej głowicy korbkowej nie mieliśmy w szkole, 
ale okazało się, że jest w wytwórni we Wrocławiu. Kiedy pojechałem do Wrocławia, Grzegorz Królikiewicz powiedziat: Musisz zrobić coś, co spowoduje, że będziesz najlepszym w Polsce operatorem kamery, który pracuje na korbkach. Więc co zrobiłem? Kupiłem skrzynkę piwa i zaprosiłem do magazynów wytwórni mojego wózkarza, który bez przerwy chodzit, pochylat się, a ja za nim prowadziłem kamere. Nie miałem nigdy przerwy w czasie planu, bo Grzegorz Królikiewicz byt człowiekiem bardzo wymagajacym. Kiedy zobaczyt, że z kimś rozmawiam, że jestem rozproszony, narysowat na dużym kartonie ósemke i powiedziat: Teraz w każdej wolnej chwili to weź krzyżem, który jest w środku kamery (Messerschmittem), prowadź cały czas przy pomocy korbek té ósemkę i badź niesamowicie precyzyjny. I ja to robiłem. Nauczyłem się dzięki Królikiewiczowi, żeby być człowiekiem nieustanie zaangażowanym w robotę. Zob. Wspomnienie Ryszarda Lenczewskiego o Grzegorzu Królikiewiczu, AMD.

${ }^{63}$ Rozmowa M. Dondzika z Krzysztofem Ptakiem, 4 czerwca 2016, AMD.

${ }^{64}$ Rozmowa M. Dondzika z Ryszardem Lenczewskim, 3 maja 2016, AMD.

65 Rozmowa M. Dondzika z Bogdanem Dziworskim, 12 maja 2016, AMD.

${ }^{66}$ Rozmowa M. Dondzika z Krzysztofem Ptakiem, 4 czerwca 2016, AMD

${ }^{67}$ Rozmowa M. Dondzika z Bogdanem Dziworskim, 12 maja 2016, AMD.

${ }^{68}$ A. Iskierko, Wieczne pretensje i... - notowata Alicja Iskierko, „Ekran” 1975, nr 7, s. 17.

${ }^{69}$ Rozmowa M. Dondzika ze Stefanem Kurzypem, 28 lipca 2020, AMD.

${ }^{70}$ Tamże.

${ }^{71}$ Rozmowa M. Dondzika z Krzysztofem Ptakiem, 4 czerwca 2016, AMD.

${ }^{72}$ I. Gruc-Rozbicka, Fechmistrz - z Bogdanem Dziworskim rozmawiała Irena Gruc-Rozbicka, „Film\&TV Kamera” 2000, nr 1, s. 6.

${ }^{73}$ Rozmowa M. Dondzika z Bogdanem Dziworskim, 12 maja 2016, AMD.

${ }^{74} \mathrm{Z}$ innowacji technicznych, jakie zastosowano w Wiecznych pretensjach, warto wspomnieć o długim obiektywie, którym kręcono ujęcia służbowego samochodu jadącego po Ryśka. Jak wspominał Stefan Kurzyp: W jednym tylko przypadku musieliśmy dostawić ciężki statyw, głowice specjalna Moy, żeby obiektyw 1200 milimetrów wypożyczony ze Szkoły Filmowej zamontować do statywu, a kamera wisiała w powietrzu przymocowana do obiektywu. Poruszało się pokręttami, bo byty delikatne i płynne panoramy w plenerze. Interesujące musiało być także ujęcie, którego reżyser nie włączył do ostatecznej wersji filmu. Była scena przejazdu po Wrocławiu ulica Świdnicka - żeśmy kamere mocowali na urządzeniu obok koła samochodu mówił Kurzyp. Rozmowa M. Dondzika ze Stefanem Kurzypem, 28 lipca 2020, AMD.

${ }^{75}$ Wypowiedź Grzegorza Królikiewicza w trakcie sesji Film - sztuka obrazu. Nowe tendencje w sztuce operatorskiej, która odbyła się w Łódzkim Domu Kultury w maju 1975 r. Zob. J. Połom, Film - sztuka obrazu, w: Realizacja obrazu filmowego i telewizyjnego, Warszawa 1980, zeszyt 21, s. 21.

${ }^{76}$ Rozmowa B. Stolarskiej z Grzegorzem Królikiewiczem, czerwiec 2010, AMD.

${ }_{77}$ Rozmowa M. Dondzika ze Zbigniewem Rybczyńskim, 4 października 2020, AMD.

78 Tamże.

79 Tamże.

${ }^{80}$ Użycie kamery Arriflex 35BL II potwierdził operator Zbigniew Rybczyński oraz asystujący mu Zbigniew Wichłacz. Można ją zaobserwować na kilku werkach do Tańczacego jastrzębia. Zob. zdjęcia o sygnaturach: 1-F-1873-112, 1-F-1873-113, 1-F-1873-8; werki dostępne na stronie http://fototeka.fn.org.pl/ (dostęp: 11.03.2021).

${ }^{81}$ Rozmowa M. Dondzika ze Zbigniewem Rybczyńskim, 4 października 2020, AMD.

${ }^{82}$ G. Królikiewicz, Z. Rybczyński, "Tańczacy jastrząb". Scenopis według powieści Juliana Kawalca, Łódź 1976, k. 45.

${ }^{83}$ Tamże.

${ }^{84}$ Tamże, k. 136.

85 M. Kuźmicki, Bogdan Mozer: najchętniej wszystko robie sam - z Bogdanem Mozerem rozmawiał Mieczysław Kuźmicki, „Magazyn Filmowy" 2016, nr 4, s. 78 .

${ }^{86} \mathrm{~W}$ trakcie kwerendy do artykułu udało mi się odnaleźć rysunek z projektem wynalazku Rybczyńskiego. Jest to praca „Kamera z ranną ręką (6)" sygnowana podpisem Zbigniewa Rybczyńskiego i datą 1975 r. Oryginał znajduje się w zbiorach Muzeum Kinematografii w Łodzi.

87 Rozmowa M. Dondzika ze Zbigniewem Wichłaczem, 25 kwietnia 2016, AMD.

${ }^{88}$ Rozmowa M. Dondzika ze Zbigniewem Rybczyńskim, 23 października 2020, AMD.

${ }^{89}$ Dokładny opis omawianej sceny można znaleźć w scenopisie filmu. Zob. G. Królikiewicz, Z. Rybczyński, dz. cyt., k. 29-30.

${ }^{90}$ Ten element scenografii odgrywa ważną rolę także w oscarowym Tangu (1980) Zbigniewa Rybczyńskiego.

${ }^{91}$ Rozmowa M. Dondzika ze Zbigniewem Rybczyńskim, 4 października 2020, AMD. Por. P. Kletowski, P. Marecki, dz. cyt., s. 92. 
${ }^{92}$ W książce Juliana Kawalca czytamy: Ale nie ma was dwóch, tylko jesteś ty sam, Michale Toporny, bo ten z lustra jest toba, a ty jesteś nim. Jesteś sam, Michale Toporny, $i$ w samotności przywdziewasz nowa skórę, i popadasz w tę, nie inna ci przedtem radość $i$ zachwyt na widok samego siebie, na nieznany ci wcześniej widok samego siebie. J. Kawalec, Tańczacy jastrząb, Państwowy Instytut Wydawniczy, Warszawa 1964, s. 97.

${ }^{93}$ Rozmowa M. Dondzika ze Zbigniewem Rybczyńskim, 4 października 2020, AMD.

94 Tamże. Por. P. Kletowski, P. Marecki, dz. cyt., s. 94.

${ }_{95}$ M. Przylipiak, Obrona Królikiewicza, w: Film polski. Twórcy i mity, red. K. Sobotka, Łódzki Dom Kultury, Łódź 1987, s. 155.

96 Rozmowa M. Dondzika ze Zbigniewem Wichłaczem, 26 kwietnia 2016, AMD. Kilka lat później Rybczyński ponownie zastosował trik z ,"cofającym się" makaronem w filmie Sceny narciarskie z Franzem Klammerem (reż. Bogdan Dziworski, Gerald Kargl, Zbigniew Rybczyński, 1980).

${ }^{97}$ E. Dolin'ska, U progu. Reportaz'z filmu "Tańczacy jastrzab", „Film” 1977, nr 3, s.19.

${ }^{98}$ Rozmowa M. Dondzika ze Zbigniewem Rybczyńskim, 23 października 2020, AMD. Por. P. Kletowski, P. Marecki, dz. cyt., s. 93.

99 Rozmowa M. Dondzika ze Zbigniewem Wichłaczem, 26 kwietnia 2016, AMD.

${ }^{100}$ B. Stolarska, Twórczość filmowa Grzegorza Królikiewicza. Sesja filmoznawcza 13-16 maja 1987 r., Łódzki Dom Kultury - DKF, Łódź 1987, s. 2.

${ }^{101}$ Rozmowa M. Dondzika ze Zbigniewem Rybczyńskim, 4 października 2020, AMD.

Michał Dondzik

\section{Bibliografia}

Dolińska, E. (1977). U progu. Reportaż z filmu „Tańczący jastrząb”. Film, (3), s. 19.

Gruc-Rozbicka, I. (2000). Fechmistrz - z Bogdanem Dziworskim rozmawiała Irena Gruc-Rozbicka. Film ETV Kamera, (1), s. 6.

Iskierko, A. (1975). Wieczne pretensje i... - notowała Alicja Iskierko. Ekran, (7), s. 17.

Janicki, S. (1973). Oko, kondycja i dobre pepegi - rozmowa Stanisława Janickiego z Bogdanem Dziworskim. Gazeta Festiwalowa, (3), s. 3.

Janicki, S. (1973). Poza kadrem - z Grzegorzem Królikiewiczem rozmawiał Stanisław Janicki. Kino, (4), s. 8.

Kawalec, J. (1964). Tańczacy jastrzab. Warszawa: Państwowy Instytut Wydawniczy.

Kletowski, P., Marecki, P. (2011). Królikiewicz. Pracuję dla przyszłości. Kraków: Korporacja Ha!Art.

Kłys, T. (2013). Od Mabusego do Goebbelsa. Weimarskie filmy Fritza Langa $i$ kino niemieckie do roku 1945. Łódź: Wydawnictwo Uniwersytetu Łódzkiego - Wydawnictwo Biblioteki PWSFTviT. 
Królikiewicz, G., Rybczyński, Z. (1976). „Tánczacy jastrzab”. Scenopis wedtug powieści fuliana Kawalca. Łódź.

Kuźmicki, M. (2016). Bogdan Mozer: najchętniej wszystko robię sam - z Bogdanem Mozerem rozmawiał Mieczysław Kuźmicki. Magazyn Filmowy, 56 (4), s. 78.

Markowski, A. (1975). Formowanie chaotycznego swiata - z Grzegorzem Królikiewiczem rozmawiał Andrzej Markowski. Kino, (7), s. 14.

Połom, J. (1980). Film - sztuka obrazu. Realizacja obrazu filmowego i telewizyjnego, (21).

Przylipiak, M. (1987). Obrona Królikiewicza. W: K. Sobotka (red.), Film polski. Tzoórcy i mity. Łódź: Łódzki Dom Kultury.

Przylipiak, M. (2007). Kino bezpośrednie. 1960-1963. Gdańsk: słowo/obraz terytoria.

Stolarska, B. (1987). Twórczość filmowa Grzegorza Królikiewicza. Sesja filmoznaweza 13-16 maja 1987 r. Łódź: Łódzki Dom Kultury - DKF.

Wertenstein, W. (1973). Móc, chcieć, wiedzieć i zdążyć. Kino, (7), s. 22.

Wojciechowski, M. (1971). KOTF wykonuje po prostu swoje obowiązki... - z Wiesławem Stemplem rozmawiał Mikołaj Wojciechowski. Ekran, (34), s. 5.

Wojciechowski, M. (1972). Pragnę wyzwolić niepokój egzystencjalny - z Grzegorzem Królikiewiczem rozmawiał Mikołaj Wojciechowski. Ekran, (30), s. 16.

Zarzycki, A. (1972). Rozpacz i zbrodnia. Magazyn Filmowy, (31), s. 11.

\author{
Keywords: \\ Bogdan Dziworski; \\ Zbigniew \\ Rybczyński; \\ Grzegorz \\ Królikiewicz; \\ Polish film; \\ cinematography; \\ film technology
}

\section{Abstract}

Michał Dondzik

Image, Technology and Polish Film: Dziworski, Rybczyński and Królikiewicz

The article is an attempt to look at the films $\mathrm{Na}$ Wylot (Through and Through, 1973), Wieczne pretensje (Permanent Objections, 1975) and Tanczacy Fastrzab (The Dancing Hawk, 1978) by Grzegorz Królikiewicz through the prism of film technology. The author refers to the memories of film operators, Bogdan Dziworski and Zbigniew Rybczyński, complementing them with accounts of other people involved in the creative and technological process of film production. The film-makers' memories collected after many years are confronted with press reports from production plans, as well as documents obtained during extensive archival research. The aim of the article is to unveil the relationship between the artistic aspirations of the cinematographer and the director on the one hand and the technological possibilities of the cinematography of Polish People's Republic on the other. 